\title{
直分解アミノ酸製造に関する研究
}

第 1 報 高温, 低温並びに折禹法分解について

東 邦雄*. 浜崎 幸男

(昭和 36 年: 2 月 14 日受理)

緒 言

泊分解アミノ酸製造汇打斿る分解の才法として従来, 高温分解法と低温分解法とが採用実施されている。 青山(1) 荒川 ${ }^{2,3)}$ 等の原料中の檪水化物利用の有利性, 香気が良好であること,グルタミン酸等アミノ酸含量が 高いこと等の点から低温分解法の膺利なことを指摘している。然し当地方業界において実施されている方法 としては高温分解によるものが多いと思われる。

吾々は主として企業に於ける工業的生産を目標として, 先ず実験室的に高温, 低温 $\left(90^{\circ} \mathrm{C}, 60^{\circ} \mathrm{C}\right)$ の 3 種の 分解圾験を試み検討したが更に，低温分解法の初期における分解操作を簡略にし，分解特間の短縮をはかる ことを目的として高温低温折衰分解法による脱脂大至の塩酸分解の基礎実験を行ない良好な成績を得たのて 報告する。

\section{I 高温, 低温分解について}

\section{1 実験方法}

$1 〜 1$, 材料 抽出脱脂大豆を使用した。年の成分は次の如くであった。

全聜素 $\quad 7.41 \%$

全糖分 $20.66 \% \quad$ (ブドー糖として

水 分 $14.69 \%$

1〜2, 試料の作製 主として青山等の方法によった。即ち

高温分解： $1 \mathrm{~m}$ のガラス管付 11 丸底フラスコを使用し，抽出脱脂大豆 $15 \mathrm{ug}$ に塩酸 $(16 \%$ ) 450m1 を添加 し，砂浴上で加熱分解し， $5 ， 8 ， 11 ， 14$ 時間毎に試料を採取した。

低滥 $\left(90^{\circ} \mathrm{C}\right)$ 分解：同一のものについて湯浴中 $\left(90 \pm 2^{\circ} \mathrm{C}\right)$ で加熱し，20，30，40，50，60時間每に採取した。 低温 $\left(60^{\circ} \mathrm{C}\right)$ 分解: $200 \mathrm{ml}$ の三角フラスコに上記抽出脱脂大至 $30 \mathrm{~g}$, 塩酸 $(16 \%) 90 \mathrm{ml}$ を添加し, 密栓して $60^{\circ} \mathrm{C}$ の恒温器中に保持し $48,72,96,120,144$ 時間毎に採取した。

1 3, 分析方法：上記の㥞にして一定時間每に約 $80 \mathrm{ml}$ を採取し, $60^{\circ} \mathrm{C}$ 分解のものについてはフラスコ 全部を使用しけたにグラスフィルターで滤過し，その濾液 $10 \mathrm{ml}$ をとり， $\mathrm{NaOH}$ で中和後, $100 \mathrm{~m} 1$ に Fillup し分析の试料とした。

全窒素はキールダール汒，アミノ態窒素はホルモール法，アンモニア態窒素は吸引法，還元糖はソモギー 变法,グルタミン酸は醉素法により定星した。

\section{2 実験結果及び考察}

第 1 表 高温分解における成分の変化

\begin{tabular}{rccccccc} 
分解時阔 & $\begin{array}{c}\mathrm{T}-\mathrm{N} \\
(\%)\end{array}$ & $\begin{array}{c}\mathrm{NH}_{2}-\mathrm{N} \\
(\%)\end{array}$ & $\begin{array}{c}\mathrm{NH}_{3}-\mathrm{N} \\
(\%)\end{array}$ & $\frac{\mathrm{NH}_{2}-\mathrm{N}}{\mathrm{T}-\mathrm{N}} \times 100$ & $\begin{array}{c}\text { Reducing } \\
\text { Sugar(\%) }\end{array}$ & \multicolumn{2}{c}{ Glutamic acid } \\
\hline 8 & 1.92 & 0.932 & 0.204 & 48.6 & 1.67 & 2.213 & 1.153 \\
11 & 1.93 & 1.118 & 0.209 & 57.9 & 1.12 & 2.392 & 1.239 \\
14 & 2.00 & 1.187 & 0.217 & 59.3 & 0.86 & 2.423 & 1.212 \\
& 2.04 & 1.225 & 0.220 & 60.0 & - & 2.402 & 1.177
\end{tabular}

第 1 表及び第 2 表より, 全晸素は比較的初期の間に略一定量に達し，以後は殆んぞ影響を受けない。又同一 条件下に怙いては，分解温度の高い場合は低い場合に比して全窒素含量は僅かながら高い。これは神津 ${ }^{5}$ )の 結果と一致している。温泉熱利用の目的から，60 $\mathrm{C}$ 低温における分解を試みたが, 第 3 表に明らかな様に, 
第 2 表 低温 $\left(90^{\circ} \mathrm{C}\right)$ 分解における成分の变化

\begin{tabular}{|c|c|c|c|c|c|c|c|}
\hline 成分 & \multirow{2}{*}{$\begin{array}{l}\mathrm{T}-\mathrm{N} \\
(\%)\end{array}$} & \multirow{2}{*}{$\begin{array}{c}\mathrm{NH}_{2}-\mathrm{N} \\
(\%)\end{array}$} & \multirow{2}{*}{$\begin{array}{c}\mathrm{NH}_{3}-\mathrm{N} \\
(\%)\end{array}$} & \multirow{2}{*}{$\underset{\mathrm{T}-\mathrm{N}}{\mathrm{NH}_{2}-\mathrm{N}} \times 100$} & \multirow{2}{*}{$\begin{array}{l}\text { Reducing } \\
\text { Sugar(\%) }\end{array}$} & \multicolumn{2}{|c|}{ Glutamic acid } \\
\hline 分解時間 & & & & & & $(\%)$ & $\mathrm{T}-\mathrm{N}=1 \mathrm{~K}$ 換算 \\
\hline 20 & 1.90 & 0.926 & 0.191 & 48.7 & 2.83 & 2.107 & 1.109 \\
\hline 30 & 1.90 & 1.061 & 0.194 & 54.3 & 2.14 & 2.213 & 1.165 \\
\hline 40 & 1.95 & 1.093 & 0.195 & 56.1 & 1.55 & 2.434 & 1. 248 \\
\hline 50 & 1.96 & 1.173 & 0.200 & 60.0 & 1.02 & 2.465 & 1.258 \\
\hline 60 & 1.97 & 1.202 & 0.204 & 61.0 & 0.63 & 2. 465 & 1. 252 \\
\hline
\end{tabular}

第 3 表 低温 $\left(60^{\circ} \mathrm{C}\right)$ 分解に打壮る成分の变化

\begin{tabular}{|c|c|c|c|c|c|c|c|}
\hline \multirow{2}{*}{ 分解時間 } & \multirow{2}{*}{$\begin{array}{l}\mathrm{T}-\mathrm{N} \\
(\%)\end{array}$} & \multirow{2}{*}{$\underset{(\%)}{\mathrm{NH}_{2}-\mathrm{N}}$} & \multirow{2}{*}{$\underset{(\%)}{\mathrm{NH}_{3}-\mathrm{N}}$} & \multirow{2}{*}{$\underset{\mathrm{T}-\mathrm{N}}{\mathrm{NH}_{2}-\mathrm{N}} \times 100$} & \multirow{2}{*}{$\begin{array}{l}\text { Reducing } \\
\text { Sugar(\%) }\end{array}$} & \multicolumn{2}{|c|}{ Glutamic acid } \\
\hline & & & & & & $(\%)$ & $\mathrm{T}-\mathrm{N}=1$ に換算 \\
\hline 48 & 1.70 & 0.489 & 0.181 & 28.8 & 5.37 & 1.064 & 0.620 \\
\hline 72 & 1.76 & 0.590 & 0.185 & 33.5 & 5.51 & 1. 138 & $0 . € 47$ \\
\hline 96 & 1.80 & 0.647 & 0.187 & 35.9 & 5.59 & 1.264 & 0.702 \\
\hline 120 & 1.84 & 0.677 & 0.190 & 36.8 & 5.50 & 1.338 & 0.727 \\
\hline 144 & 1.87 & 0.855 & 0.191 & 45.7 & 5.31 & 1.496 & 0.800 \\
\hline
\end{tabular}

還元糖を除く全成分含量が低く，なおこの温度に沶いては，蛋白質の分解率 $\left(\mathrm{NH}_{2}-\mathrm{N} / \mathrm{T}-\mathrm{N} \times 100\right)$ は, 1414

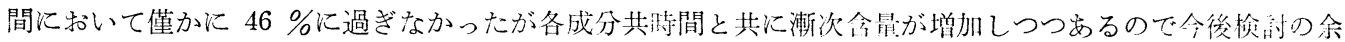
地がある様沁思われる。

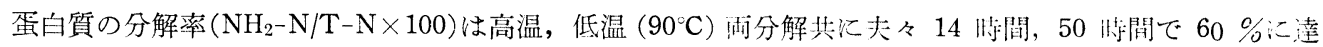
し極めて良好であった。

$\mathrm{NH}_{3}-\mathrm{N}$ は，分解温度が高くなる程生成量が高く，しかもいずれの場合に括いても $\mathrm{NH}_{3}-\mathrm{N}$ は極的て早い 時間に放出される様である。

還元糖については温度の高い程糖の分解は促進され，60ㅇ 0 分解では余り変化がなく $5 \%$ 以上の值走示り

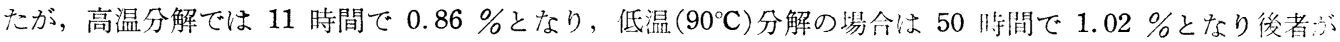

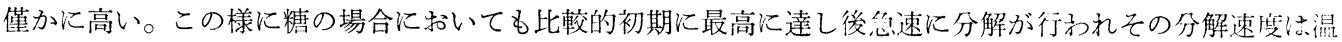
度が高い程大きい。

グルタミン酸については，低温 $\left(90^{\circ} \mathrm{C}\right)$ 分解の方が高温分解よりも僅かに高いがこれについては青山等も同 様のことを述べている。

\section{II 折衰法について}

\section{1 実験方法}

$1 \sim 1 ，$ 実験材料は前述の脱脂大豆を用いた。

1 2, 試料の作製：前述の方法により $1 \mathrm{~m}$ のガラス管は 11 丸底フラスコを使用し，抽出脱脂大至 $150 \mathrm{~g}$ 亿 塩酸 $(16 \%) 450 \mathrm{ml}$ 添加し, 砂浴上で 2 時間分解した後, 直セに湯浴中 $\left(90 \pm 2^{\circ} \mathrm{C}\right)$ に移し分解を続けた。試 料の採取は湯浴汇移す直前（高温分解 2 時間後）並びに移して後 20，30将間汇夫々行った。

\section{2 実験結果及び考察}

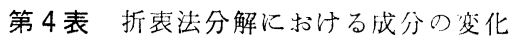

\begin{tabular}{|c|c|c|c|c|c|c|c|}
\hline \multirow[t]{2}{*}{ 成分 } & \multirow{2}{*}{$\begin{array}{l}\mathrm{T}-\mathrm{N} \\
(\%)\end{array}$} & \multirow{2}{*}{$\underset{(\%)}{\mathrm{NH}_{2}-\mathrm{N}}$} & \multirow{2}{*}{$\underset{(\%)}{\mathrm{NH}_{3}-\mathrm{N}}$} & \multirow{2}{*}{$\frac{\mathrm{NH}_{2}-\mathrm{N}}{\mathrm{T}-\mathrm{N}} \times 100$} & \multirow{2}{*}{$\begin{array}{l}\text { Reducing } \\
\text { Sugar(\%) }\end{array}$} & \multicolumn{2}{|c|}{ Glutamic acid } \\
\hline & & & & & & $(\%)$ & $\mathrm{T}-\mathrm{N}=1$ 亿換算 \\
\hline 2 & 1.82 & 0.757 & 0.176 & 41.6 & 3.73 & 1. 496 & 0.822 \\
\hline 22 & 1.94 & 1.195 & 0.191 & 61.5 & 2.21 & 2.265 & 1.168 \\
\hline 32 & 1.99 & 1.294 & 0.195 & 65.0 & 1.88 & 2.423 & 1.218 \\
\hline
\end{tabular}

各時間毎の試料の分析值を第 4 表に示した。

この表汇見られる如く短時間高温で分解することにより大部分の可溶性窈素を生じ，析衰法 22〜32 洔間 目の分解液中の全窒素については表 1，2で見られる両分解に比べて差がないとみてよい。

$\mathrm{NH}_{2}-\mathrm{N}$ については表 $1 ， 2$ 亿おいて，高温分解では 14 時間で， $1.225 \%$ ，低温 $\left(90^{\circ} \mathrm{C}\right)$ 分解では 60時間

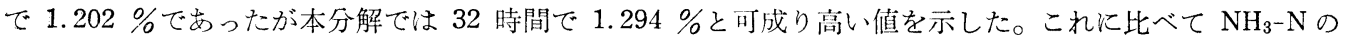


生成量は㲎合に低くこの絬果帒白質の分解率 $\left(\mathrm{NH}_{2}-\mathrm{N} / \mathrm{T}-\mathrm{N} \times 100\right)$ は高く, 高温, 低温両分解の $60 \%$ 対し て 32 将間で $65 \%$ の験值を示している。

直接還元糖においても，32 時間分解後 $1.88 \%$ 残糖值を示し，この值は表 1,2 の高温, 低温两分解の 夫々 11,50 洔間沉拈る $0.86 \%, 1.02 \%$ に比べて可成り高いと見てよい。

グルタミン酸は牌間の経過と共に增加しているがこの実験においてはその最高值を示す時間を㧽めなかっ

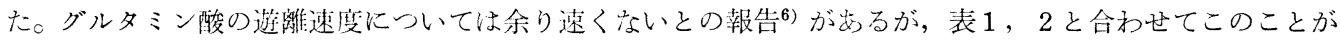
肯定されると思 5 。

以上の結果より脱脂大放の壏酸加水分解においてこの験では, 全空素, $\mathrm{NH}_{2}-\mathrm{N}$, 直接還元糖などの成分 は比較的早い時期に遊離されその後は徐々に上星するが，直接還元糖はその後分解される速度が早くなり減 少する傾向が心る。この折哀法分解によるものは 32 時間程度の分解時間で女る程度各成分の利用度が他に 比べて改善される。

脱脂大与を原料とする塩酸加水分解によるアミノ酸液の製造について，高温低温並びに折衰法分解に持け る成分の変化を裯べた。

1）全窒素，坐白質の分解率，グルタミン酸含有量の有利性から高温分解では 11〜14 時間, 低温分解で は 50 時間程度が良好であった。

2) 折衷分解では 32 時間程度の比較的短い分解時間において全窒素は高温低温両分解に比べて殆んど差 がなかった年起白質の分解率は高温，低温両分解よりも可成り高い值を示した。

3）グルタミン酸の生成黒は，折哀法に打いては，低温分解よりも僅かに劣り，高温分解と殆んど同様の 結果を得た。精分は折哀分解法が最乎多かった。

終りに臨み本引験について特にグルタミン酸定量法を琵児島大学農学部蟹江松雄教授，並びに同文理学部 富永直友助教授の御指奨を仰ぎ，又当場勝田常芳部長には終始御指導御鞭撻をいただいたとに対し感激の 意を表します。文当場研究生重信忠身不の協力に対して感謝します。

文

献

1）青山：関唒アミノ酸技術部会報, 第 2 報, 昭 24 年

2) 荒川: 间上

第 1 報, 昭 23 年

3) 荒川：本誌, 7 ( 5 ) 45 (1950)

4) 青山：調味科学, 5 ( 2 ) 19 (1957)

5) 神津：日農化，31，327(1957)

6) 微生物学講坐 9 , 醴酵食品 P 236 